\title{
Ocena lokalnych wad mikrostruktury - korelacja wyników pomiarów wiroprądowych i oznaczeń mikrotwardości
}

\section{Evaluation of the local microstructure defects - correlation of the eddy current measurements and microhardness indications}

\section{Streszczenie}

Procesy odpuszczania i obecność wad strukturalnych powodują obniżenie twardości materiału. Celem badań była ocena przydatności układu pomiarowego: Wirotestu 1000 oraz sond specjalistycznych o ograniczonym polu pomiaru do badania lokalnych zmian mikrostruktury. Przedmiotem prób było wykrywanie pomiarami wiroprądowymi lokalnych zmian struktury na przykładzie powierzchni miejscowo zdeformowanych przez wykonanie nacięć metodą elektroiskrową, oraz pomiary mikrotwardości i badania zgładów metalograficznych. Pomiary wykonywano na próbkach ze stali 40HNMA oraz na wałku z tej samej stali. Stwierdzono możliwość wykrywania lokalnych zmian mikrostruktury przy równoczesnej wykrywalności pęknięć. Wyniki pomiarów zweryfikowano pomiarami mikrotwardości i badaniami metalograficznymi. Zaobserwowano równoczesną możliwość stosowania metody prądów wirowych do ujawniania innych zmian struktury niewykrytych pomiarami mikrotwardości.

Słowa kluczowe: prądy wirowe, mikrotwardość, mikrostruktura

\section{Wstęp}

\section{Koncepcja pracy}

Metodę prądów wirowych zastosowano na próbkach referencyjnych i kołach zębatych w celu oceny wpływu obróbki cieplnej, zmian chropowatości i obecności pęk-

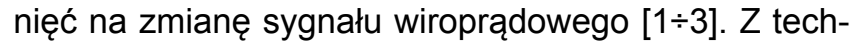
nologicznego punktu widzenia istotne jest także wykrywanie miejscowych, często niewielkich powierzchni

\section{Abstract}

The tempering processes and presence of the structural defects cause decreasing of the material hardness. The purpose of the studies was to evaluate the usefulness of the measurement system: Wirotest 1000 and specialized probes with a limited field of view for testing the microstructure changes. The subject of the tests was to detect local changes in the structure using the eddy current method. Measurements were conducted on the surface, which was locally deformed by WEDM cutting. In addition, the studies included measurements of microhardness and metallographic examination. Measurements were done on the reference samples made of the 40HNMA steel and on the shaft surface made of the same steel. It was possible to clearly detect local changes in the microstructure and at the same time detect cracks. The measurement results were verified by microhardness measurement and metallographic examination. The eddy current detection of structural changes has been observed, which have not been detected by microhardness measurements.

Keywords: eddy current, microhardness, microstructure

o strukturze zmienionej wskutek lokalnego przegrzania lub zgniotu [4], które mogą być przyczyną wadliwości wyrobów, np. kół zębatych lub wałków. Dotyczy to zwłaszcza wykrywania austenitu szczątkowego [5] i jego przemiany w bainit, powodującej zwiększenie wymiarów geometrycznych wyrobu, prowadzących do zatarcia, np. elementów łożysk tocznych. Sam austenit szczątkowy stanowi niekorzystny składnik strukturalny, charakteryzujący się obniżoną twardością oraz

Dr hab. inż. Tomasz Babul, mgr inż. Sylwester Jończyk, Tadeusz Samborski - Instytut Mechaniki Precyzyjnej, Warszawa. 
obniżoną przewodnością cieplną, co powoduje np. występowanie przypaleń szlifierskich w czasie szlifowania.

W pomiarach wiroprądowych sygnał na ogół uśrednia dane $z$ większej powierzchni. W omawianej pracy pomiary wiroprądowe wykonywano na stosunkowo małych powierzchniach. Pole pomiaru sondy miało średnicę ok. $4 \mathrm{~mm}$. Do weryfikacji wyników badań metodą prądów wirowych zastosowano metodę pomiaru mikrotwardości - szczególnie przydatną do wykrywania lokalnych zmian mikrostruktury.

Poszukiwano korelacji między średnimi wartościami mikrotwardości, które mają charakter punktowy, a danymi wiroprądowymi.

Dana mikrotwardość nie zawsze odpowiada takiej samej strukturze. Na przykładzie gotowego wałka sprawdzano, czy wiroprądy wykrywają tego rodzaju rozbieżności.

\section{Metodyka pomiarów i próbki pomiarowe}

Do badań zastosowano układ pomiarowy: Wirotest 1000 oraz sondy o zróżnicowanej częstotliwości nominalnej od $250 \mathrm{kHz}$ do $1 \mathrm{MHz}$. Konstrukcja sond i uchwytów umożliwiała utrzymanie stałej odległości 0,05 mm od powierzchni badanej.

Oznaczenia mikrotwardości badanych próbek wykonywano twardościomierzem Struers DuraScan 70 - metodą Vickersa HV0,2. Porównywano wyniki pomiarów wiroprądowych sondami o ograniczonym polu widzenia z wynikami oznaczania mikrotwardości w tych samych punktach.

Jako materiał do badań służyły próbki referencyjne o średnicy zewnętrznej $44 \mathrm{~mm}$ i wysokości $30 \mathrm{~mm}$. Próbki te wycięto z walców ze stali 40HNMA po hartowaniu i odpuszczaniu. Próbki oznakowano w następujący sposób:

- symbol A 430 - temperatura odpuszczania $430^{\circ} \mathrm{C}$,

- symbol B 490 - temperatura odpuszczania $490^{\circ} \mathrm{C}$,

- symbol C 540 - temperatura odpuszczania $540^{\circ} \mathrm{C}$.

Na próbkach referencyjnych - po zdjęciu charakterystyk wiroprądowych - metodą elektroiskrową wykonano nacięcia wzorcowe o szerokości rysy $0,25 \mathrm{~mm}$ i głębokości od 0,2 do 2,0 mm. Nacięcia te wykonano po jednej stronie próbki, w odległości $15 \mathrm{~mm}$ od krawędzi. a)

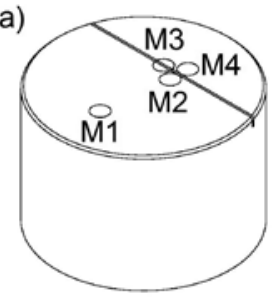

b)

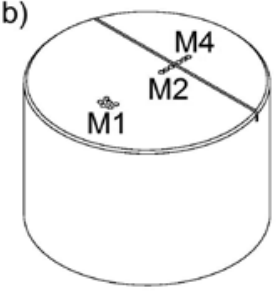

Rys. 1. Rozmieszczenie miejsc pomiarowych na powierzchni próbki z nacięciem: a) miejsca pomiarów wiroprądowych, b) punkty pomiarów mikrotwardości

Fig. 1. Arrangement of the measuring points on the sample surface with a incision: a) a measuring points of the eddy current testing, b) a microhardness measuring points
Na rysunku 1 przedstawiono rozmieszczenie miejsc pomiarów wiroprądowych i mikrotwardości na powierzchni próbki z nacięciem. W każdym punkcie wykonano po 10 pomiarów wiroprądowych. Pomiary mikrotwardości wykonywano w odległości od 0,04 do 5,00 mm od nacięcia, łącznie 10 pomiarów.

Ponadto wykonano pomiary wiroprądowe i oznaczenia mikrotwardości na powierzchni wybranych zębów i fragmentów powierzchni walcowej wałka W przedstawionego na rysunku 2 . Na rysunku zaznaczono powierzchnie, na których dokonano pomiarów.

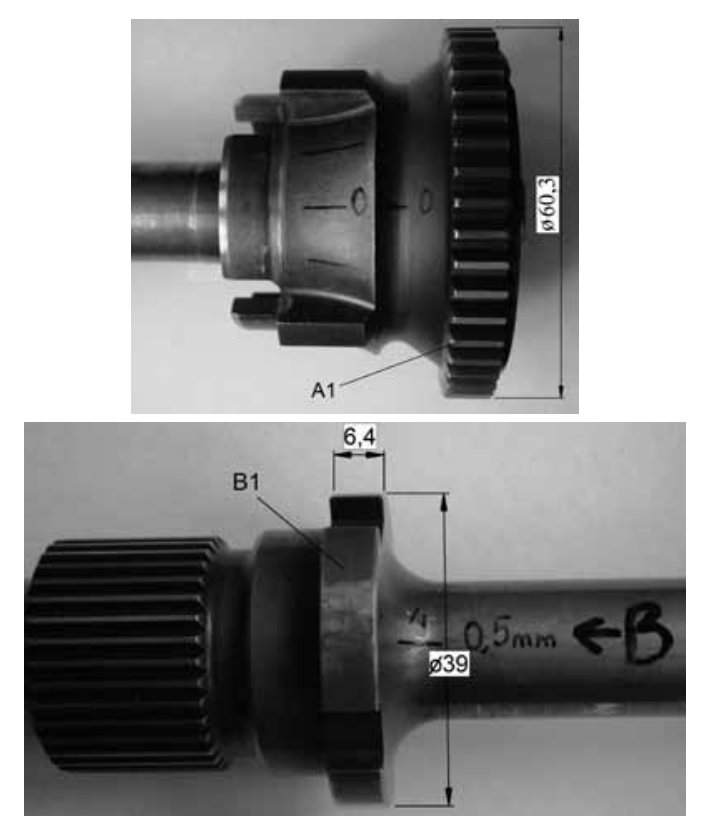

Rys. 2. Wałek W - miejsca pomiarów wiroprądowych i oznaczeń mikrotwardości: A1 na powierzchniach górnych zębów, B1 na powierzchni walcowej

Fig. 2. The $W$ shaft - places of the eddy current testing and determinations of microhardness: A1 on the top surfaces of teeth, B1 on the cylindrical surface

\section{Badania próbek referencyjnych}

\section{Charakterystyka próbek}

W tablicy I podano średnie wyniki pomiarów wiroprądowych wykonane dla całego zbioru próbek przed nacinaniem. Wykonywano je sondami o różnej częstotliwości znamionowej. Dane te charakteryzują wpływ temperatury odpuszczania na wartość sygnału wiroprądowego przy różnych częstotliwościach nominalnych sondy.

Tablica I. Średnie wyniki pomiarów wiroprądowych wykonane dla całego zbioru próbek przed nacinaniem

Table I. The average eddy current measurements made for the entire set of samples before cutting

\begin{tabular}{|c|c|c|c|}
\hline \multirow{2}{*}{ Rodzaj sondy } & \multicolumn{3}{|c|}{ Rodzaj próbki } \\
\cline { 2 - 4 } & A 430 & B 490 & C 540 \\
\hline $\mathrm{SNC} / 13 / 0051,0 \mathrm{MHz}$ & 17 & -44 & -76 \\
\hline $\mathrm{SNC} / 13 / 0040,5 \mathrm{MHz}$ & -1 & -56 & -86 \\
\hline $\mathrm{SNC} / 06 / 001250 \mathrm{kHz}$ & -6 & -41 & -61 \\
\hline
\end{tabular}


Stwierdzono, że ze wzrostem temperatury odpuszczania - obniżeniem twardości - sygnał wiroprądowy maleje.

Na rysunku 3 pokazano wykres zależności sygnału Wirotestu 1000 + sonda $250 \mathrm{kHz}$ w funkcji głębokości nacięcia dla próbek o różnej temperaturze odpuszczania. Stwierdzono, że im głębsze nacięcie, tym wyższy sygnał wiroprądowy - niezależnie od temperatury odpuszczania próbek.

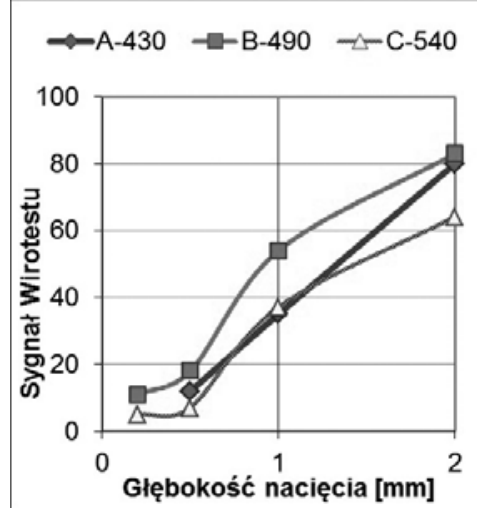

Rys. 3. Zależność sygnału Wirotestu $1000+$ sonda 250 kHz od głębokości nacięcia w próbkach o różnej temperaturze odpuszczania

Fig. 3. The dependence between the signal Wirotest $1000+$ probe $250 \mathrm{kHz}$ and the depth of incision in the samples with different annealing temperatures

\section{Wyniki pomiarów próbek referencyjnych}

W tablicy II zestawiono wyniki pomiarów na powierzchniach próbek $z$ nacięciami $1,0 \mathrm{~mm}$. W pomiarach każdorazowo jako powierzchnię odniesienia, czyli sygnał 0 , przyjmowano punkt 1 - obszar poza nacięciem.

Tablica II. Wyniki pomiarów wiroprądowych na powierzchniach próbek z nacięciami $1,0 \mathrm{~mm}$. Pomiar sondą SNC/06/001 $250 \mathrm{kHz}$

Table II. The results of the eddy current measurements on the surface of samples with $1.0 \mathrm{~mm}$ incisions. The measurement probe $\mathrm{SNC} / 06 / 001250 \mathrm{kHz}$

\begin{tabular}{|c|c|c|c|c|}
\hline \multirow{4}{*}{ Próbka } & \multicolumn{4}{|c|}{ Głębokość nacięcia 1,0 mm } \\
\cline { 2 - 5 } & M1 & M2 & M3 & M4 \\
\cline { 2 - 5 } & 0 & przegrzanie & $1,0 \mathrm{~mm}$ & przegrzanie \\
\hline \multirow{3}{*}{ A 430 } & 0 & -24 & 37 & -41 \\
\cline { 2 - 5 } & 0 & -26 & 33 & -42 \\
\cline { 2 - 5 } & 0 & -24 & 34 & -44 \\
\hline \multirow{3}{*}{ średnia } & 0 & -25 & 35 & -42 \\
\hline \multirow{3}{*}{ B 490 } & 0 & -41 & 40 & -44 \\
\cline { 2 - 5 } & 0 & -35 & 52 & -35 \\
\cline { 2 - 5 } & 0 & -38 & 61 & -31 \\
\hline \multirow{2}{*}{ średnia } & 0 & -38 & 51 & -37 \\
\hline \multirow{3}{*}{ C 540 } & 0 & -65 & 20 & -29 \\
\cline { 2 - 5 } & 0 & -65 & 28 & -20 \\
\cline { 2 - 5 } & 0 & -70 & 38 & -15 \\
\hline \multirow{2}{*}{ średnia } & 0 & -65 & 29 & -21 \\
\hline
\end{tabular}

Dla miejsc dla miejsc oznaczonych symbolem M1 oraz symbolami M2 i M3 wyraźnie widoczne są zmiany sygnałów wiroprądowych, spowodowane zmianami mikrostrukturalnymi (np. efektem miejscowego przegrzania, co wynika z obniżenia sygnału w porównaniu z powierzchnią niezmienioną). Sygnały pochodzące od nacięć (miejsca M3) mają wartości dodatnie, a ich znacząca różnica pozwala wnioskować o możliwości równoczesnego wykrywania przypaleń i pęknięć.

W tablicy III zestawiono wyniki średnie pomiaru mikrotwardości próbek z nacięciem $1 \mathrm{~mm}$ z powierzchni poza nacięciem, przed nacięciem i za nacięciem. Wykonano po 10 pomiarów z naciskiem HV0,2 w odległości od 0,04 do 5,00 mm od krawędzi nacięcia. Zaobserwowano duże odchylenia standardowe dla pomiarów mikrotwardości, mimo że zgodnie $z$ informacją producenta, a także w przypadku pomiarów miejsc o jednorodnej strukturze, odchylenia standardowe mieściły się w zakresie $1 \div 2 \%$. Otrzymane wyniki porównywano z pomiarami wiroprądowymi, ponieważ sygnały zbierane były z tych samych powierzchni (pole widzenia zastosowanych sond miało średnicę ok. $5 \mathrm{~mm}$ ).

Tablica III. Zestawienie wyników średnich pomiaru mikrotwardości próbek: poza nacięciem, przed nacięciem i za nacięciem

Table III. Summary of the results of the average measurement of microhardness: outside the incision, in front of the incision, behind the incision

\begin{tabular}{|c|c|c|c|}
\hline Próbka & Miejsce pomiaru & Symbol & Twardość HV0,2 \\
\hline \multirow{4}{*}{ A 430 } & poza nacięciem & M1 & 447 \\
\cline { 2 - 4 } & przed nacięciem & M2 & 416 \\
\cline { 2 - 4 } & za nacięciem & M4 & 390 \\
\hline \multirow{4}{*}{ B 490 } & poza nacięciem & M1 & 405 \\
\cline { 2 - 4 } & przed nacięciem & M2 & 388 \\
\cline { 2 - 4 } & za nacięciem & M4 & 390 \\
\hline \multirow{3}{*}{ C 540 } & poza nacięciem & M1 & 372 \\
\cline { 2 - 4 } & przed nacięciem & M2 & 355 \\
\cline { 2 - 4 } & za nacięciem & M4 & 364 \\
\hline
\end{tabular}

Na wykresach (rys. 4 i 5) porównano wartości średnich oznaczeń wiroprądowych i pomiarów mikrotwardości próbek z nacięciem $1 \mathrm{~mm}$.

W miejscach oznaczonych symbolami M2 i M3 (rys. 1) wyraźnie widoczne jest obniżenie sygnału wiroprądowego w porównaniu z powierzchnią odniesienia o symbolu M1 - wzorcową (sygnał Wirotestu $1000=0$ ), spowodowane obniżeniem twardości - efektem zmiany struktury wskutek nacinania. Widoczna jest dobra zbieżność wyników oznaczeń mikrotwardości i pomiarów wiroprądowych. Sygnały od nacięć (M4) są dodatnie (wzrost sygnału), podobnie jak w pomiarach bez przypaleń. Różnica jest znacząca, co pozwala wnioskować o możliwości równoczesnej wykrywalności przypaleń i pęknięć. 

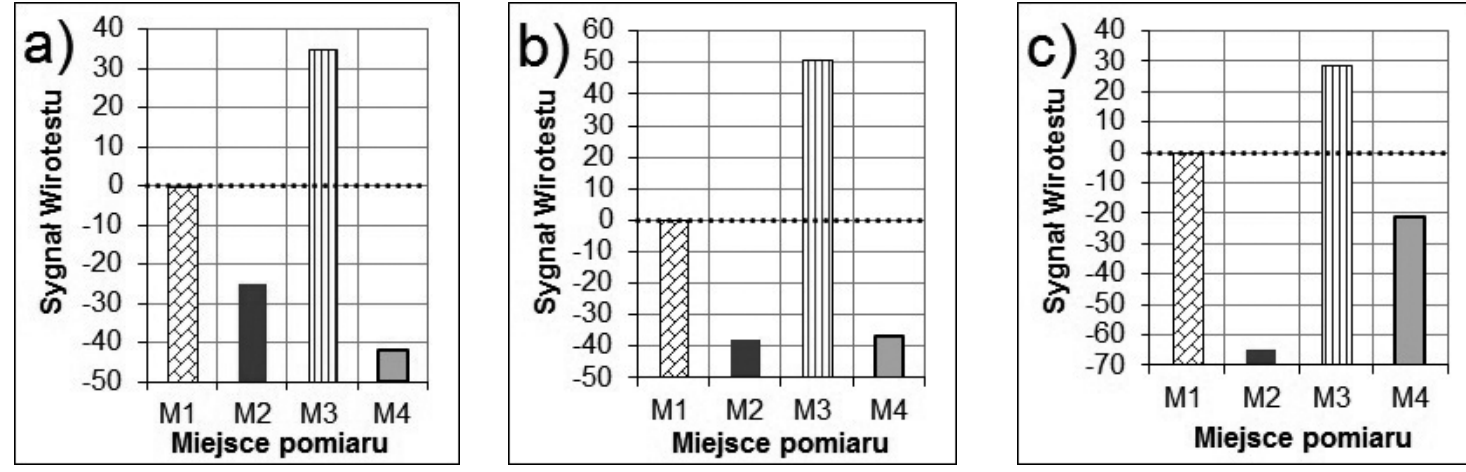

Rys. 4. Wyniki pomiarów wiroprądowych próbek: a) A 430, b) B 490, c) C 540. Nacięcie $1 \mathrm{~mm}$

Fig. 4. The results of the eddy current measurements of the samples: a) A 430, b) B 490, c) C 540. Incision $1 \mathrm{~mm}$
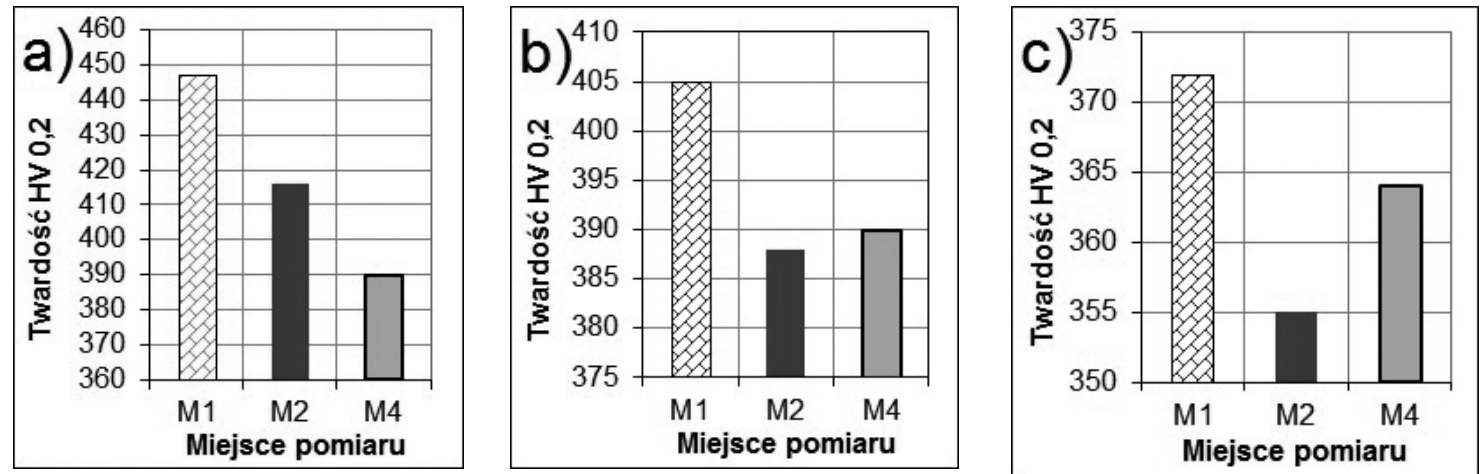

Rys. 5. Wyniki oznaczeń mikrotwardości próbek: a) A 430, b) B 490, c) C 540. Nacięcie $1 \mathrm{~mm}$

Fig. 5. The results of the microhardness determinations of the samples: a) A 430, b) B 490, c) C 540. Incision $1 \mathrm{~mm}$

Próbka C 540 z nacięciem $2 \mathrm{~mm}$ po polerowaniu została wytrawiona nitalem. Na rysunku 6 przedstawiono mikrofotografię zgładu (pow. 200x) w obszarze M1: a) z odciskami po pomiarach mikrotwardości, b) bez odcisków. Na rysunku 7 pokazano powierzchnię przy krawędzi nacięcia M2 z odciskami po pomiarach mikrotwardości, a na rysunku 8 powierzchnię przy krawędzi nacięcia M4 poza obszarem pomiarów mikrotwardości. $\mathrm{Na}$ przedstawionych rysunkach wyraźnie widoczna jest zmiana struktury, wykryta prądami wirowymi i potwierdzona pomiarami mikrotwardości. Wynik ten uzyskano pomimo zdjęcia części materiału z powierzchni w czasie polerowania - widoczna jest różnica wymiarów odcisku na rdzeniu i fragmentach z nacięciami.

\section{Podsumowanie wyników badań próbek referencyjnych}

Stwierdzono korelację między pomiarami wiroprądowymi a wartościami pomiarów mikrotwardości, co może być przydatne do wykrywania lokalnych zmian mikrostruktury przy zastosowaniu tej metody nieniszczącej. Obserwacje metalograficzne potwierdziły te wyniki. Wykonane pomiary wykazały, że istnieje możliwość jednoznacznego wykrywania lokalnych zmian struktury przy równoczesnej wykrywalności nieciągłości.
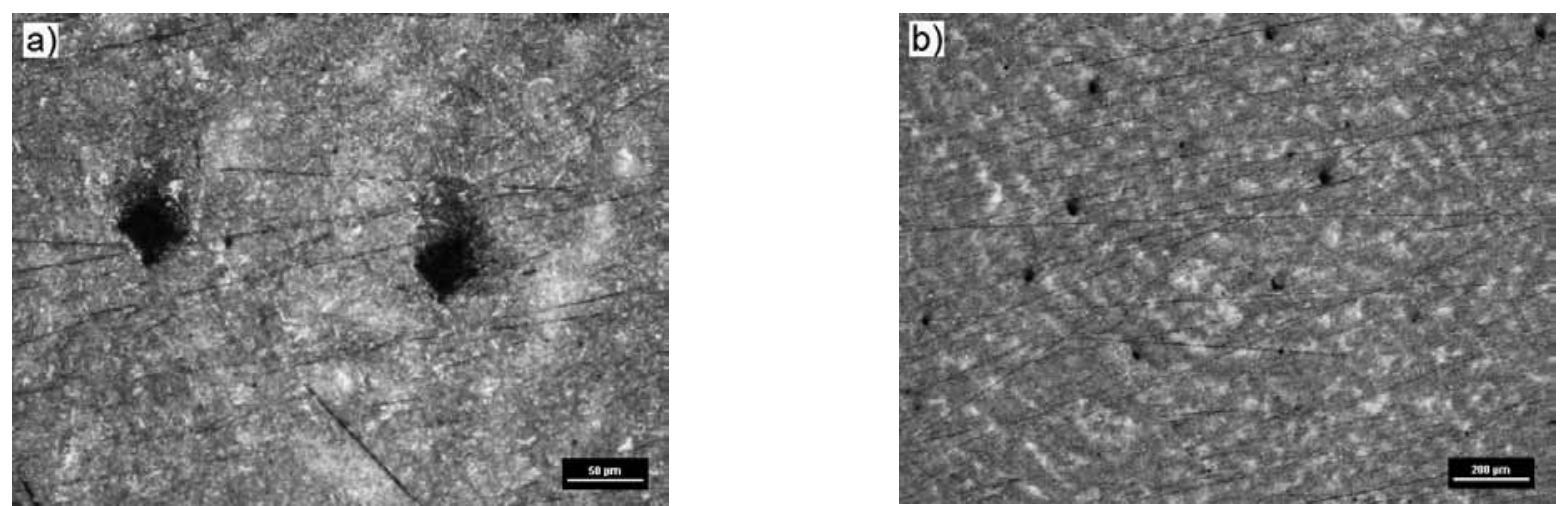

Rys. 6. Miejsce M1 - rdzeń: a) z odciskami po pomiarach mikrotwardości, b) bez odcisków

Fig. 6. The M1 place - the core: a) with the microhardness dents, b) without the microhardness dents 

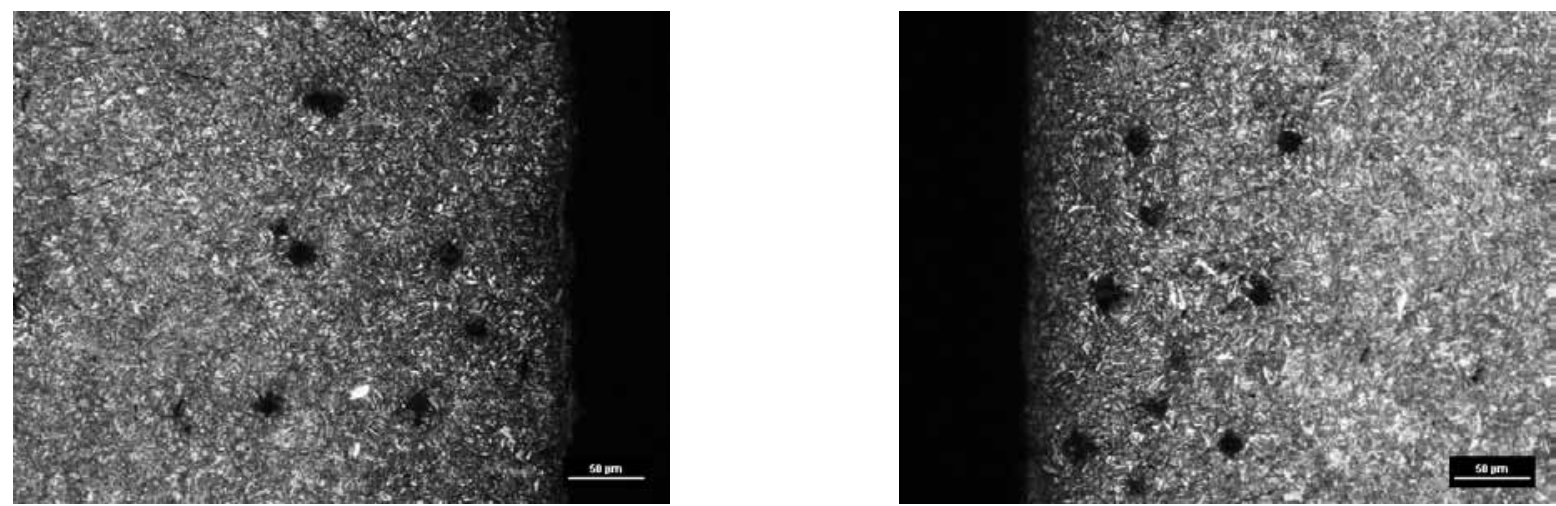

Rys. 7. Krawędzie nacięcia M2 i M4 z odciskami po pomiarach mikrotwardości

Fig. 7. The edges of the incision M2 and M4 with the microhardness dents
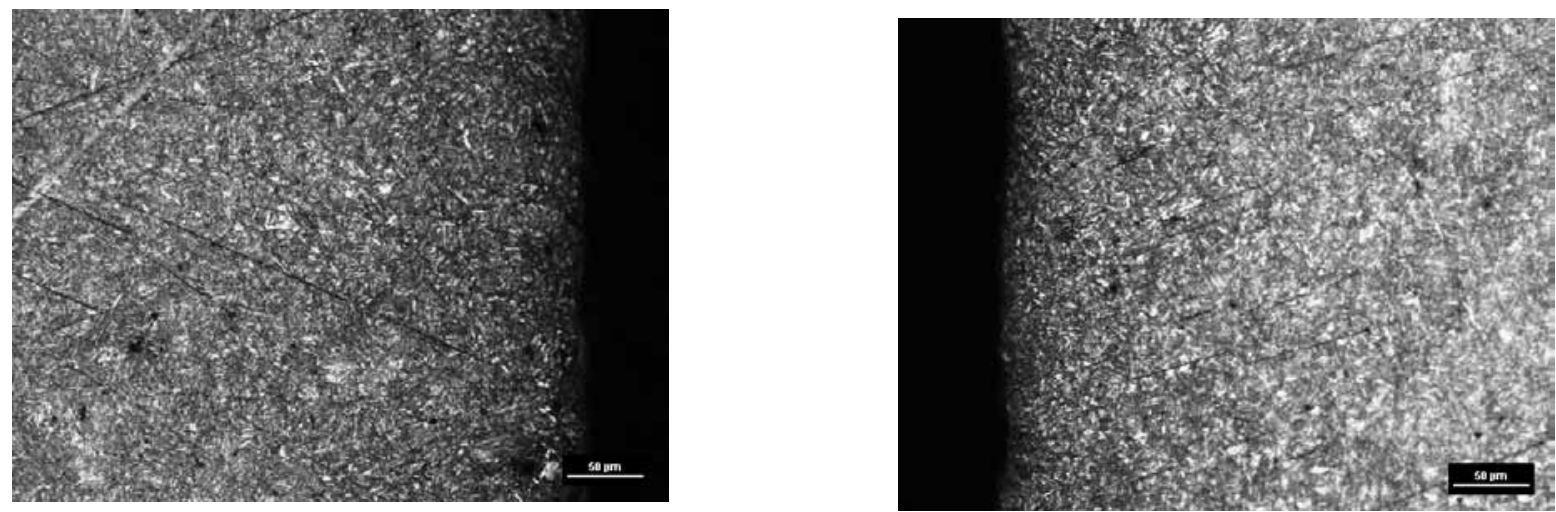

Rys. 8. Krawędzie nacięcia M2 i M4 poza obszarem pomiarów mikrotwardości

Fig. 8. The edges of the incision M2 and M4 outside the microhardness measuring area

\section{Pomiary wałka z uzębieniem}

Przedmiotem pomiarów był gotowy wałek $z$ uzębieniem wykonany ze stali $40 \mathrm{HNMA}$. Pomiary wiroprądowe i oznaczenia mikrotwardości wykonywano na powierzchni A1 - na górnej powierzchni zębów, oraz B1 - na powierzchni walcowej.

$\mathrm{Na}$ rysunku 9 przedstawiono lokalizację punktów pomiarowych wiroprądowych i mikrotwardości na powierzchni zęba. Pomiary na powierzchniach zębów wykonywano na 4 zębach (co czwarty ząb), oznaczonych jako pozycje: $0,4,8,12$.

W tablicy IV i na rysunkach 10 i 11 zestawiono wyniki pomiarów wałka na powierzchniach A1 i B1, otrzymanych metodą wiroprądową z zastosowaniem sondy

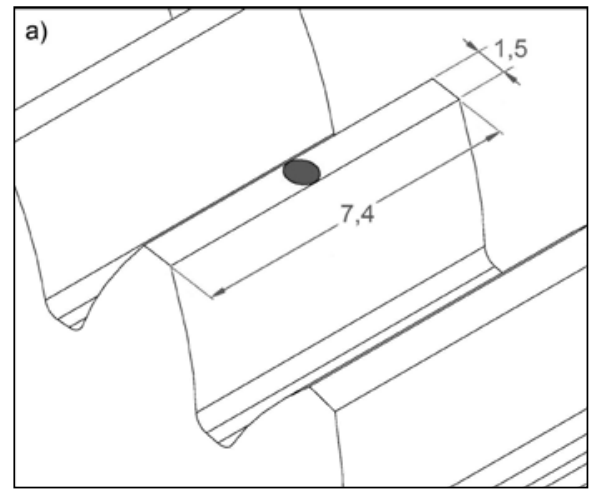

$250 \mathrm{kHz}$ oraz uzyskanych przez pomiar mikrotwardości HV0,2.

Zarówno z danych z tablicy IV, jak i wykresów (rys. 10 i 11) wynika jednoznacznie, że w miejscu A1 poz. 8 i w miejscu B1 poz. 12 należy się spodziewać imperfekcji niezwiązanych ze zmiana mikrotwardości, co potwierdzają mikrofotografie (rys. 12). Na rysunku 12a (A1 poz. 8) widoczne jest wydzielenie i mikropęknięcie, niewykryte przez pomiar mikrotwardości, a sygnalizowane wzrostem wartości sygnału wiroprądowego. Na rysunku 12b (B1 poz. 12) widoczne są wydzielenia i wtrącenia, sygnalizowane obniżeniem sygnału wiroprądowego, a niewykryte pomiarem mikrotwardości. W pozostałych punktach pomiarowych zależność sygnału Wirotestu od mikrotwardości ma charakter prostoliniowy (linia trendu).

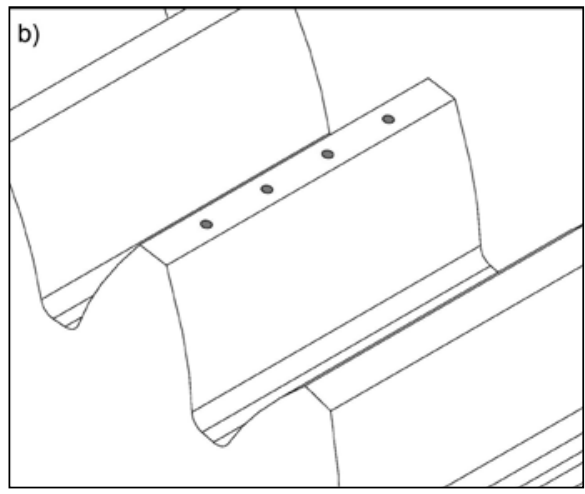

Rys. 9. Rozmieszczenie punktów pomiarowych na powierzchni zęba A1: a) pomiary wiroprądowe, b) pomiary mikrotwardości

Fig. 9. Arrangement of the measuring points on the tooth surface A1: a) the eddy current testing, b) the microhardness measurements 


\begin{tabular}{|c|c|c|c|c|}
\hline Pozycja & A1 HV0,2 & A1 wir & B1 HV0,2 & B1 wir \\
\hline 0 & 638 & 0 & 425 & 0 \\
\hline 4 & 653 & 8 & 413 & -5 \\
\hline 8 & 627 & 28 & 419 & -3 \\
\hline 12 & 621 & -7 & 421 & -20 \\
\hline
\end{tabular}

Tablica IV. Porównanie wyników pomiarów wałka: wiroprądowych sondą $250 \mathrm{kHz}$ (średnie z 5 pomiarów) i mikrotwardości HV0,2 (średnie z 10 pomiarów)

Table IV. A comparison of the measurements results of the shaft: the eddy current testing with the probe $250 \mathrm{kHz}$ (average of 5 measurements) and the HV0.2 microhardness measurements (average of 10 measurements)
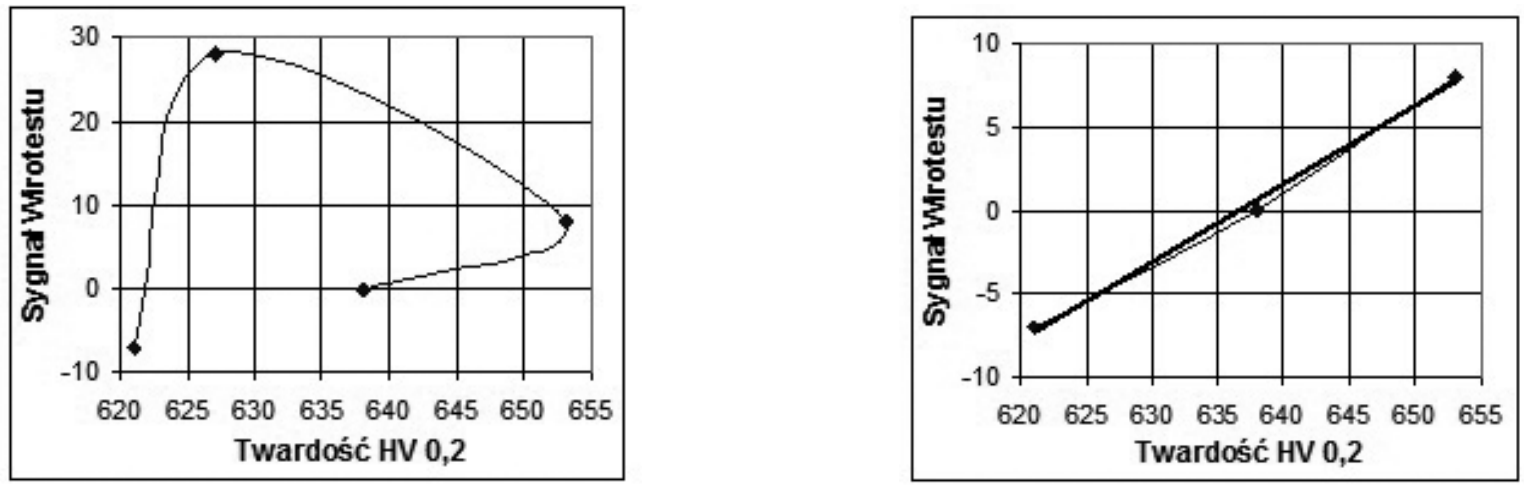

Rys. 10. Zależność sygnałów wiroprądowych od mikrotwardości HV0,2 na powierzchniach A1 wałka

Fig. 10. The dependence of eddy current signals from the microhardness HV0,2 on the surfaces $A 1$ of the shaft
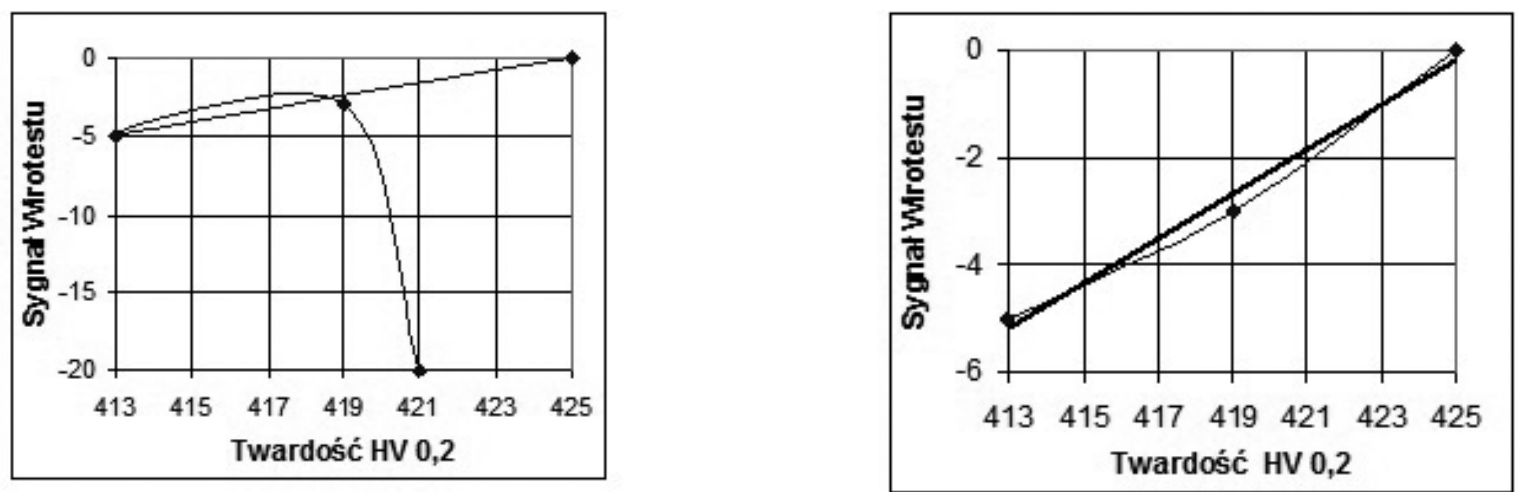

Rys. 11. Zależność sygnałów wiroprądowych od mikrotwardości HV 0,2 na powierzchni B1 wałka

Fig. 11. The dependence of eddy current signals from the microhardness $H V 0,2$ on the surfaces $B 1$ of the shaft
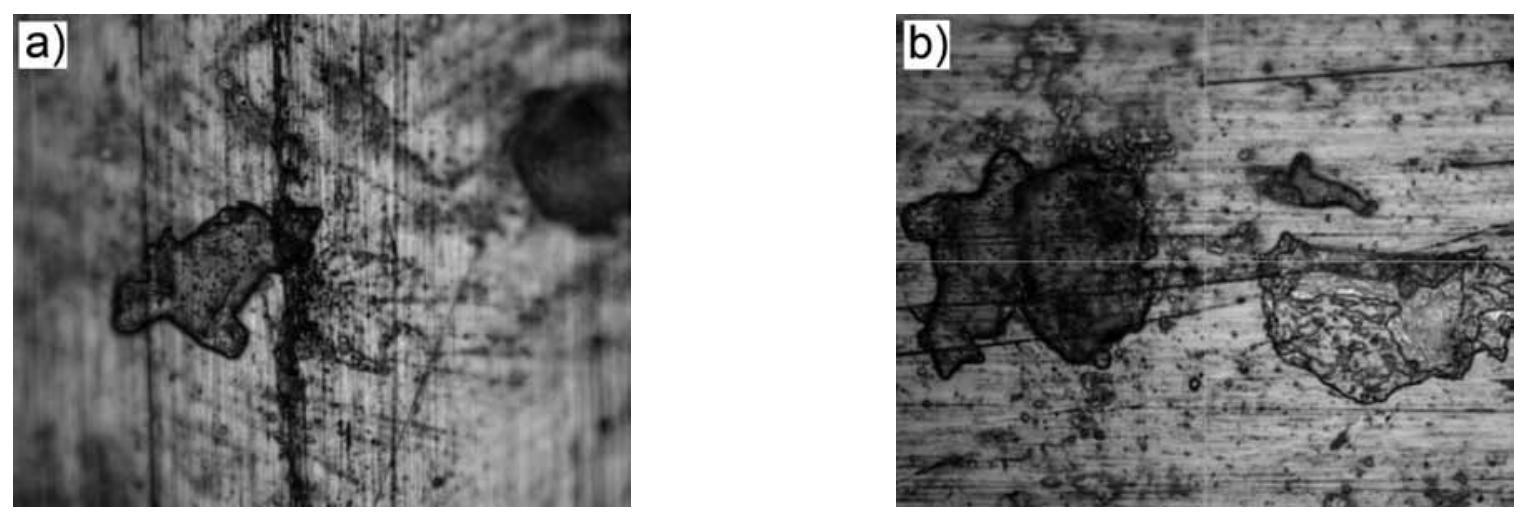

Rys. 12. Mikrofotografie (pow. 60x) wad na powierzchni zębów wałka; a) A1 poz. 8 - wydzielenie i mikropęknięcie, b) B1 poz. 12 - wydzielenia, wtrącenia

Fig. 12. The microphotographs (magn. 60x) of the surface defects of the shaft teeth; a) A1 position 8 - precipitations and microcrack, b) B1 position 12 - precipitations, inclusions 


\section{Wnioski}

Na podstawie przeprowadzonych badań sformułowano następujące wnioski:

- Stwierdzono, że przy zastosowaniu układu pomiarowego: Wirotest 1000 + sondy specjalistyczne można wykrywać lokalne imperfekcje strukturalne.
- Uzyskano korelację - jednoznaczną zależność sygnału wiroprądowego od mikrotwardości w obszarach pozbawionych lokalnych imperfekcji strukturalnych.

- Stwierdzono, że zastosowana aparatura wiroprądowa może posłużyć do wykrywania lokalnych wad struktury niewykrywanych pomiarami mikrotwardości.

\section{Literatura}

[1] Babul T., Jończyk S.: Wybrane aspekty badania kół zębatych metodą prądów wirowych. Przegląd Spawalnictwa, vol. LXXXIV, 2012 nr 13/12, s.12-15.

[2] Babul T., Jończyk S., Samborski T., Włodarczyk S.: Wykrywanie niejednorodności materiału i lokalnych zmian mikrostruktury metodą prądów wirowych. Przegląd Spawalnictwa, vol. LXXXV, nr 12/2013, s. 25-28.
[3] Babul T., Jończyk S., Samborski T., Włodarczyk S.: Zastosowanie Wirotestów do kontroli kół zębatych. Mat. 40 KKBN. Warszawa 2011.

[4] Dybiec M., Dybiec Cz., Włodarczyk S., Kozłowska A.: Control effects by shot peening with application of the eddy current method. 15th WCNDT, Roma 2000.

[5] Dybiec Cz., Kozłowska A.: Ocena skłonności stali do przypaleń szlifierskich metodą prądów wirowych. Mat. 27 KKBN Międzyzdroje 1998, s. 77-80.

Praca finansowana w ramach NCBiR INNOTECH 165/12012, LOWIR:

"Zastosowanie i wdrożenie prądów wirowych do badania i wykrywania wad materiałowych na częściach lotniczych wirujących"

\section{PLANY SPAWANIA - TEORIA I PRAKTYKA - JACEK SKANIA}

\section{Cena}

Cena 1 egzemplarza książki Jacka Słani:

Plany spawania - teoria i praktyka wynosi:

80 zł (w tym 5\% VAT)

\section{W celu zamówienia książki w Redakcji należy wypełnić formularz zamieszczony obok i przesłać go w formie faksu, skanu lub listu na adres:}

REDAKCJA - Przegląd Spawalnictwa AW SIMP

ul. Świętokrzyska 14a, 00-050 Warszawa tel.: 2282725 42, faks: 223361479 e-mail: pspaw@ps.pl

Wpłaty należy dokonać na rachunek bankowy: Bank BPH S.A. Oddział w Warszawie 45106000760000320000431836
Zamawiam książkę Plany spawania - teoria i praktyka

w Redakcji Przegląd Spawalnictwa w liczbie .... egz.

Imię i nazwisko

Firma

Adres

NIP

Kontakt do osoby zamawiającej:

Oświadczam, że jestem podatnikiem VAT i upoważniam firmę do wystawienia faktury bez podpisu 